\title{
Staphylococcus pulvereri sp. nov., Isolated from Human and Animal Specimens
}

\author{
J. ZAKRZEWSKA-CZERWIŃSKA, A. GASZEWSKA-MASTALARZ, B. LIS, \\ A. GAMIAN, AND M. MORDARSKI* \\ Institute of Immunology and Experimental Therapy, Polish Academy \\ of Sciences, Czerska 12, 53-114 Wrocław, Poland
}

\begin{abstract}
A new coagulase-negative species of the genus Staphylococcus, Staphylococcus pulvereri, was isolated from human and animal specimens. The complete 16S rRNA sequence of the type strain of $S$. pulvereri, NT215, was determined and compared with the sequences of $16 \mathrm{~S}$ rRNAs from the other staphylococci. Strains of $S$. pulvereri were differentiated from other novobiocin-resistant Staphylococcus species by their biochemical activities, cell wall composition, and levels of genetic relatedness. The type strain of this species is NT215 $\left(=\mathrm{PCM}_{2443^{\mathrm{T}}}\right)$.
\end{abstract}

The genus Staphylococcus comprises 30 species (6), including the recently described $S$. delphini (21), S. felis (5), S. muscae (4), S. pasteuri (1), and S. piscifermentans (20). The taxonomic status of these species was determined by a combination of biochemical, chemical, molecular, and physiological properties. Staphylococcus species have been isolated from various mammals and birds, as well as from food of animal origin. It is likely that novel species will be discovered if additional host organisms and new environments are examined.

In the course of the identification of staphylococci from various human and animal specimens, several previously undescribed coagulase-negative strains were found. In this report, we depict a new species, $S$. pulvereri.

(A portion of this work was presented at the European Culture Collections Organisation XII Meeting, June 1993, Istanbul, Turkey.)

\section{MATERIALS AND METHODS}

Bacterial strains. Five epidemiologically unrelated coagulase-negative staphylococcal strains were examined during our taxonomic studies (Table 1). Glucose-yeast extract-peptone was used as a basal medium.

Morphological and colonial characteristics. Colony morphology and pigmentation were observed on $\mathrm{P}$ agar plates, as reported by Kloos et al. $(6,7)$. Cell morphology was observed from Gram-stained smears.

Phenotypic characteristics. The production of free coagulase was determined by the method established by Sperber and Tatini (19). In order to detect catalase activity, a small amount of cells was taken directly from a colony on a plate, added to a drop of $3 \% \mathrm{H}_{2} \mathrm{O}_{2}$, and examined for release of oxygen bubbles. Anaerobic growth was tested in Evans' semisolid thioglycolate medium (2) or in Wilkins agar (23). Growth was investigated at different temperatures and $\mathrm{NaCl}$ concentrations $(7.5,10,15,17.5$, and $20 \%$ ), as described by Kloos et al. (7). Enzymatic reactions were detected with the ID32 Staph kit (Biomerieux, Marcy l'Etoile, France). Susceptibility to various antibiotics was determined on Mueller-Hinton agar by a standard diffusion technique with disks containing ampicillin, cephaloridine, chloramphenicol, clindamycin, erythromycin, fosfomycin, fusidic acid, gentamicin, kanamycin, lincomycin, minocycline, nitrofurantoin, novobiocin, oxacillin, penicillin, pristinamycin, rifampin, tetracycline, tobramycin, and vancomycin.

Isolation and analysis of teichoic acids. Teichoic acids were isolated according to the method of Schleifer et al. (17). Liberated sugars were analyzed as alditol acetates by gas chromatography-mass spectrometry on a Hewlett-Packard apparatus (model 5971A) with a type HP-1 glass capillary column $(0.2 \mathrm{~mm}$ by $12 \mathrm{~m})$ with temperature programming at $8^{\circ} / \mathrm{min}$, from 150 to $270^{\circ} \mathrm{C}$ in the electron ionization $(70 \mathrm{eV})$ mode.

Isolation of cell wall and amino acid analysis. From approximately $500 \mathrm{mg}$ of dry cells, walls were prepared by mechanical disruption with an X-press

* Corresponding author. Mailing address: Institute of Immunology and Experimental Therapy, Polish Academy of Sciences, Czerska 12, 53-114 Wrocław, Poland. Fax: 48-71-679111. Electronic mail address: gaszew@immuno.pan.wroc.pl.
(Pharmacia LKB, Uppsala, Sweden). After further purification, carried out as depicted by Schleifer (16), the amino acid composition of complete cell wall was analyzed by gas chromatography-mass spectrometry with a Hewlett-Packard 5971A apparatus under the conditions described above. Standards of amino acids were hydrolyzed, derivatized, and analyzed in the same way.

Analysis of fatty acids. The fatty acid spectrum of whole-cell methanolysates was determined according to the method of Minnikin and Goodfellow (10). Methyl esters of fatty acids were analyzed by gas chromatography-mass spectrometry (Hewlett-Packard model 5971A) under the conditions established for the analysis of the teichoic acids (described above). The relative ratio among different fatty acids was expressed as a mean value of 3 days.

DNA isolation and manipulations. Genomic DNA was prepared according to the method of Mordarski et al. (11). Lysozyme-resistant strains were treated with lysostaphin (Sigma; $5 \mathrm{U} / \mathrm{g}$ [wet biomass]) for $3 \mathrm{~h}$ at $37^{\circ} \mathrm{C}$. Purification of DNA fragments and cloning techniques were described previously (24).

PCR. PCR was performed in a UNO-thermoblock (Biometra). The reaction mixture $(100 \mu \mathrm{l})$ contained $1 \mu \mathrm{M}$ primers, $1 \mu \mathrm{g}$ of DNA template, all four deoxynucleotide triphosphates at $0.2 \mathrm{mM}$ each, $50 \mathrm{mM} \mathrm{KCl}, 10 \mathrm{mM}$ Tris- $\mathrm{HCl}$ $(\mathrm{pH} 8.3), 1.5 \mathrm{mM} \mathrm{MgCl} 2,0.01 \%$ gelatin, and $2.5 \mathrm{U}$ of $T a q$ polymerase.

DNA sequence determination. $16 \mathrm{~S}$ genes coding for rRNA of $S$. pulvereri $\mathrm{NT} 215^{\mathrm{T}}$ were amplified in vitro by PCR (13) with oligonucleotide primers complementary to highly conserved regions of the 16S rRNA (8). The amplified DNA was sequenced either directly or after its cloning in the vector pUC18. Sequencing of both DNA strands was performed with the dideoxy-chain termination method (15) with T7 DNA polymerase (Promega Corp., Madison, Wis.) and $\left[\alpha-{ }^{35}\right.$ S ATP (Amersham).

$16 S$ rRNA sequence analysis. The $16 \mathrm{~S}$ rRNA sequences of the following organisms belonging to the genus Staphylococcus found in the GenBank Data Library were used for comparison (accession numbers are in parentheses): $S$. aureus (X68417), S. epidermidis (Z26894 i Z22809), S. haemolyticus (X66100), S. hominis (X66101), and S. saprophyticus (L20250). The sequences of S. muscae, S. schleiferi, and $S$. sciuri were taken from reference 4.

The 16S rRNA gene sequence of $S$. pulvereri consisted of 1,009 nucleotides corresponding to $65 \%$ of the full $16 \mathrm{~S}$ rRNA primary structure. Approximately 1,000 nucleotides of this sequence (ranging from positions 80 to 1077; Escherichia coli numbering system) were aligned with those of other bacteria, and sequence similarities were calculated (22). A phylogenetic tree was generated by the neighbor-joining method (14). Bootstrap values were obtained by using the programs of the PHYLIP package (3).

DNA base composition. The $\mathrm{G}+\mathrm{C}$ content of DNA was extrapolated from the

TABLE 1. Designations and sources of the $S$. pulvereri strains

\begin{tabular}{lll}
\hline Strain & \multicolumn{1}{c}{ Other designation } & \multicolumn{1}{c}{ Source } \\
\hline NT215 $^{\mathrm{T}}$ & $\begin{array}{c}\text { B92/78 Lodenkamper, Sweden } \\
\text { NT165 } \\
\text { Marples 100 844 (phage study, } \\
\text { British Isles) }\end{array}$ & $\begin{array}{l}\text { Hip infection } \\
\text { Human }\end{array}$ \\
NT310 & $\begin{array}{c}\text { Marples 100 940 (phage study, } \\
\text { Sweden) }\end{array}$ & Human \\
NT312 & $\begin{array}{c}\text { Marples 100 958 (phage study, } \\
\text { Sweden) }\end{array}$ & Human \\
NT322 & $\begin{array}{c}\text { 1xK7/22, Heczko, Poland } \\
\text { Carcass of diseased } \\
\text { chicken }\end{array}$ \\
\hline
\end{tabular}


TABLE 2. Characteristics of the $S$. pulvereri strains

\begin{tabular}{|c|c|c|c|c|c|}
\hline Characteristic & $\mathrm{NT} 215^{\mathrm{T}}$ & NT165 & NT310 & NT312 & NT322 \\
\hline Colony size $\geq 6 \mathrm{~mm}$ & + & + & + & - & $\mathrm{ND}^{a}$ \\
\hline Aerobic growth & + & + & + & + & + \\
\hline Anaerobic growth & \pm & \pm & \pm & \pm & \pm \\
\hline Catalase & + & + & + & + & + \\
\hline Clumping factor & - & - & - & - & - \\
\hline Staphylocoagulase & - & - & - & - & - \\
\hline \multicolumn{6}{|l|}{$\begin{array}{l}\text { Acid produced aerobically } \\
\text { from: }\end{array}$} \\
\hline D-Arabinose & - & - & - & - & - \\
\hline D-Cellobiose & - & - & - & - & - \\
\hline D-Fructose & + & + & + & + & + \\
\hline D-Glucose & + & + & + & + & + \\
\hline Lactose & - & + & - & + & + \\
\hline Maltose & + & + & + & + & + \\
\hline D-Mannitol & - & + & - & - & - \\
\hline D-Mannose & - & - & - & + & + \\
\hline$N$-Acetylglucosamine & - & - & - & - & + \\
\hline Raffinose & - & - & - & - & - \\
\hline D-Ribose & - & - & - & - & - \\
\hline Sucrose & + & + & + & + & + \\
\hline D-Trehalose & + & - & - & - & + \\
\hline D-Turanose & - & - & - & - & - \\
\hline \multicolumn{6}{|l|}{ Enzyme tests } \\
\hline Acetoin production & + & + & + & + & - \\
\hline Alkaline phosphatase & - & + & + & + & - \\
\hline Arginine arylamidase & - & - & - & - & - \\
\hline Arginine dihydrolase & - & - & + & + & + \\
\hline Esculin (hydrolysis) & - & - & $?$ & - & - \\
\hline$\beta$-Galactosidase activity & - & - & - & - & + \\
\hline$\beta$-Glucuronidase activity & + & - & - & - & + \\
\hline Nitrate reduction & - & $?$ & + & + & + \\
\hline Ornithine decarboxylase & - & - & - & - & - \\
\hline Pyrrolidonyl arylamidase & - & - & - & - & + \\
\hline Urease activity & + & - & + & - & + \\
\hline \multicolumn{6}{|l|}{ Resistance to: } \\
\hline Lysostaphin $(200 \mu \mathrm{g} / \mathrm{ml})$ & - & - & - & - & - \\
\hline Lysozyme $(400 \mu \mathrm{g} / \mathrm{ml})$ & + & + & + & + & + \\
\hline $\begin{array}{c}\text { Growth in the presence of } \\
15 \%(\mathrm{wt} / \mathrm{vol}) \mathrm{NaCl}\end{array}$ & + & + & + & + & + \\
\hline
\end{tabular}

${ }^{a} \mathrm{ND}$, not determined.
DNA melting temperature as described by Marmur and Doty (9). DNA isolated from $E$. coli $\mathrm{K}-12(51.5 \mathrm{~mol} \% \mathrm{G}+\mathrm{C})$ was used as a control.

DNA relatedness. DNA from various strains was fixed on nitrocellulose membranes (25). After preincubation in Denhardt's solution, hybridizations were performed at $54^{\circ} \mathrm{C}$ for $24 \mathrm{~h}$ in $4 \times$ SSC $(1 \times$ SSC is $0.15 \mathrm{M} \mathrm{NaCl}$ plus 0.015 $\mathrm{M}$ sodium citrate) containing $20 \%$ deionized formamide. Genomic DNA was labelled in vitro by nick translation (12) with deoxy- $\left[1^{\prime}, 2^{\prime}, 5^{\prime}-{ }^{3} \mathrm{H}\right]$ cytidine $5^{\prime}$ triphosphate (Amersham). All experiments were repeated three times, and average readings were recorded.

Nucleotide sequence accession number. The 16S rRNA sequence of the type strain of $S$. pulvereri, NT215, was deposited in the GenBank database under accession number U12764.

\section{RESULTS AND DISCUSSION}

Physiological and biochemical characteristics. The characteristics of five strains of $S$. pulvereri are shown in Table 2. All of the strains were coagulase negative and resistant to novobiocin. They all produced catalase, grew aerobically, were facultatively anaerobic, and were susceptible to ampicillin, cephaloridine, chloramphenicol, clindamycin, erythromycin, fosfomycin, fusidic acid, gentamicin, kanamycin, lincomycin, minocycline, nitrofurantoin, oxacillin, penicillin, pristinamycin, and vancomycin. Four strains (NT165, NT215 ${ }^{\mathrm{T}}$, NT310, NT312) were resistant to tetracycline.

When the $S$. pulvereri strains were tested by the micromethod ID32 Staph System, the reactions of three of them (NT165, NT310, NT312) resembled those of $S$. epidermidis, whereas the reactions of the strains NT215 ${ }^{\mathrm{T}}$ and NT322 corresponded to those of $S$. warneri and $S$. simulans, respectively.

Molecular characterization. (i) The $G+C$ content of DNA from $S$. pulvereri strains. The DNA base compositions of the five strains ranged from 27 to $30 \mathrm{~mol} \% \mathrm{G}+\mathrm{C}$; these values are slightly lower than the values ( 30 to $39 \mathrm{~mol} \%$ ) obtained for the previously described staphylococci (6).

(ii) DNA-DNA relatedness. The DNAs from all five strains shared more than $85 \%$ homology (Table 3 ) but only up to $36 \%$ homology with 30 other defined Staphylococcus species.

(iii) Sequence of the 16S rRNA gene. A DNA fragment from S. pulvereri NT215 ${ }^{\mathrm{T}}$ containing a $16 \mathrm{~S}$ rRNA gene was amplified, cloned, and sequenced. A comparison of this sequence with the ones published from $S$. haemolyticus, $S$. hominis, $S$.

TABLE 3. Levels of DNA-DNA relatedness between $S$. pulvereri strains and other species in the genus Staphylococcus ${ }^{a}$

\begin{tabular}{|c|c|c|c|}
\hline Source of unlabeled DNA ${ }^{b}$ & $\begin{array}{l}\text { tedness with } \\
\text { reri NT2 } 215^{\mathrm{T}}\end{array}$ & Source of unlabeled $\mathrm{DNA}^{b}$ & $\begin{array}{l}\text { tedness with } \\
\text { ereri NT215 }\end{array}$ \\
\hline S. arlettae DSM 20672 & 17 & S. kloosii DSM 20676 & 9 \\
\hline S. aureus DSM 20231 & 5 & S. lentus DSM $20352 \ldots \ldots$ & 36 \\
\hline 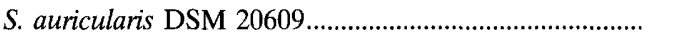 & 7 & 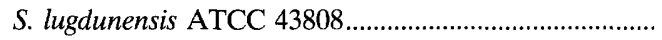 & 3 \\
\hline 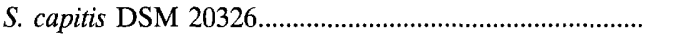 & 14 & S. muscae CCM 4175 .. & 5 \\
\hline S. caprae DSM 20608 & 24 & 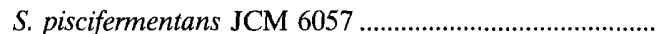 & 4 \\
\hline 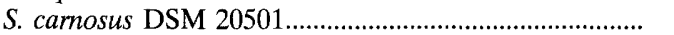 & 18 & S. pulvereri NT165 & 86 \\
\hline 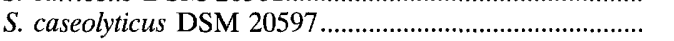 & 9 & S. pulvereri NT215 & 100 \\
\hline 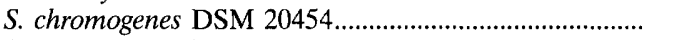 & 15 & S. pulvereri NT310 & 94 \\
\hline S. cohnii DSM 20260 & 22 & S. pulveren NT312 & 100 \\
\hline 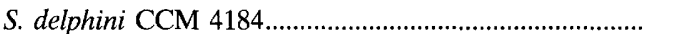 & 5 & S. pulvereri NT320 & 85 \\
\hline 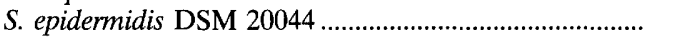 & 13 & S. saccharolyticus DSM 20359 & 8 \\
\hline S. equorum DSM 20674 & 12 & 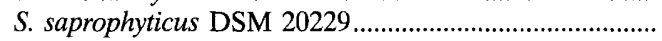 & 17 \\
\hline 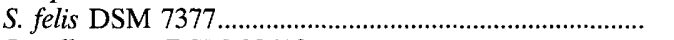 & 12 & S. schleiferi ATCC 43809 & 8 \\
\hline S. gallinarum DSM 20610 & 26 & S. sciuri DSM 20345 & 12 \\
\hline 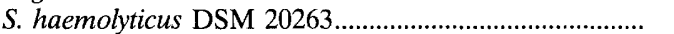 & 16 & S. simulans DSM 20322 & 9 \\
\hline S. hominis DSM 20328 & 11 & S. warneri DSM $20316 \ldots$ & 14 \\
\hline 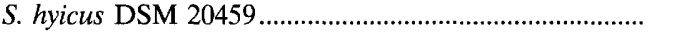 & 6 & 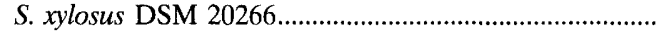 & 17 \\
\hline S. intermedius DSM 20373 & 4 & & \\
\hline
\end{tabular}

\footnotetext{
${ }^{a}$ Hybridizations were carried out under stringent conditions.

${ }^{b}$ Abbreviations: ATCC, American Type Culture Collection, Rockville, Md.; CCM, Czechoslovak Collection of Microorganisms, Brno, Czech Republic; DSM, Deutsche Sammlung von Mikroorganismen, Braunschweig, Germany; JCM, Japan Collection of Microorganisms, Riken, Saitama, Japan.
} 
TABLE 4. Similarity values for sequences of genes coding for $16 \mathrm{~S}$ rRNA of $S$. pulvereri and other staphylococcal species

\begin{tabular}{|c|c|c|c|c|c|c|c|c|}
\hline \multirow[b]{2}{*}{ Species } & \multicolumn{8}{|c|}{$\%$ Similarity to: } \\
\hline & 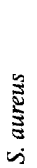 & 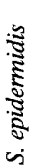 & 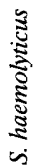 & 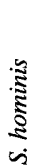 & 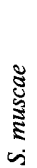 & 的 & 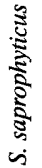 & 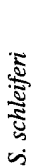 \\
\hline
\end{tabular}

S. aureus

S. epidermidis

haemolyticus $\quad 97.5 \quad 97.2$

S. hominis

S. muscae

S. pulvereri

S. saprophyticus

S. schleiferi

S. sciuri

$97.3 \quad 97.7$

$96.7 \quad 97.2 \quad 96.6$

$\begin{array}{llll}96.5 & 96.1 & 95.5 & 96.3\end{array}$

$\begin{array}{llll}97.3 & 96.8 & 97.8 & 97.6\end{array}$

$\begin{array}{llll}96.3 & 96.9 & 95.8 & 96.2\end{array}$

Sciuri

muscae, S. saprophyticus, S. sciuri, and S. schleiferi showed that the strain NT215 ${ }^{\mathrm{T}}$ was a member of the genus Staphylococcus and is most closely related to $S$. sciuri $(98.4 \%$ similarity [Table 4 and Fig. 1]).

Cell wall analysis. (i) Amino acids. The cell walls of all five $S$. pulvereri strains contained a glycine-rich peptidoglycan, which is typical of staphylococci. All of them had an L-LysAla--Gly ${ }_{4-5}$ peptidoglycan type. The presence of L-Ala in the interpeptide bridge is also a characteristic feature of $S$. lentus and $S$. sciuri (18). Serine was not detected in any of the strains analyzed.

(ii) Teichoic acid. The teichoic acids from all five strains analyzed corresponded to the poly(glycerolphosphate) type, with ribose and $N$-acetylglucosamine (GlcNAc) as the main constituents. Ribitol could not be detected.

(iii) Cellular fatty acid composition. Methanolysates of complete $S$. pulvereri cells were mainly composed of $i s o-$ and anteiso-branched fatty acids with 15,17 , and 19 carbon atoms. Long-chain-saturated $\mathrm{C}_{20: 0}$ and iso- $\mathrm{C}_{21: 0}$ were found, in addition to small amounts of unsaturated $C_{17: 1}$ acids. $C_{20: 0}$ fatty

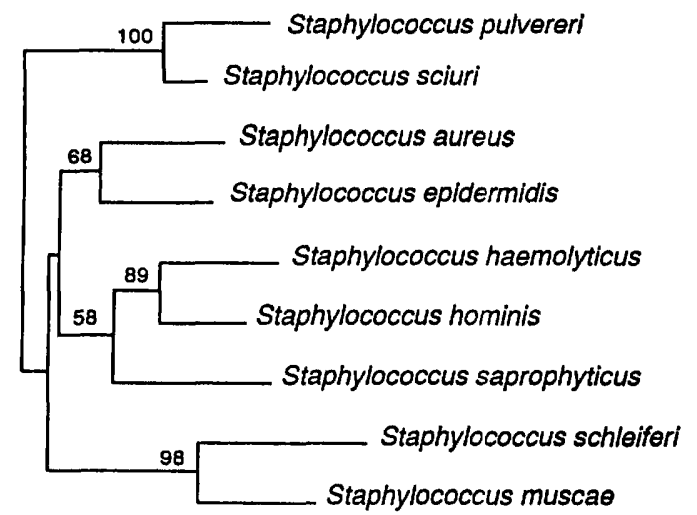

0.01

FIG. 1. Phylogenetic tree constructed by the neighbor-joining method showing the relationships among $S$. pulvereri and other staphylococcal species. Bootstrap values are indicated at branching points.
TABLE 5. Characteristics that differentiate $S$. pulvereri from other novobiocin-resistant staphylococci ${ }^{a}$

\begin{tabular}{|c|c|c|c|c|c|c|c|c|c|c|}
\hline Characteristic & 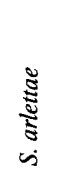 & ن & 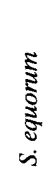 & 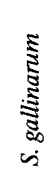 & $\begin{array}{l}\tilde{b} \\
\frac{8}{3} \\
\dot{3}\end{array}$ & 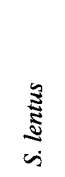 & 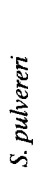 & 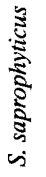 & 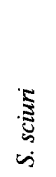 & 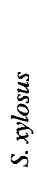 \\
\hline Colony size $\geq 6 \mathrm{~mm}$ & d & $\mathrm{d}$ & - & + & d & - & d & + & + & + \\
\hline Colony pigment & + & - & - & $\mathrm{d}$ & d & d & $\mathrm{d}$ & $\mathrm{d}$ & $\mathrm{d}$ & d \\
\hline Alkaline phosphatase & $(+)$ & - & $(+)$ & $(+)$ & d & $( \pm)$ & d & - & + & d \\
\hline Esculin (hydrolysis) & - & - & $\mathrm{d}$ & + & $\mathrm{d}$ & + & - & - & + & d \\
\hline Acetoin production & - & d & - & - & $\mathrm{d}$ & - & d & + & - & d \\
\hline Urease & - & - & + & + & $\mathrm{d}$ & - & $\mathrm{d}$ & + & - & + \\
\hline \multicolumn{11}{|l|}{ Acid produced from: } \\
\hline D-Maltose & + & (d) & $\mathrm{d}$ & + & $\mathrm{d}$ & d & + & + & (d) & + \\
\hline D-Mannitol & + & d & + & + & + & + & d & d & + & + \\
\hline Raffinose & + & - & - & + & - & + & - & - & - & - \\
\hline Sucrose & + & - & + & + & $( \pm)$ & + & + & + & + & + \\
\hline D-Trehalose & + & + & + & + & + & + & $\mathrm{d}$ & + & + & + \\
\hline D-Turanose & + & - & d & + & - & $( \pm)$ & - & + & $( \pm)$ & d \\
\hline
\end{tabular}

$a+, 90 \%$ or more strains positive;, $\pm 90 \%$ or more strains weak positive; - , $90 \%$ or more strains negative; d, 11 to $89 \%$ of strains positive. Parentheses indicate a delayed reaction. Table 5 is adapted from work by Kloos et al. (6).

acid had recently been reported to be characteristic for the genus (18).

(iv) Description of $S$. pulvereri sp. nov. The description of the species $S$. pulvereri (pul'.ver. er.i. L. gen. n. pulvereri, in honor of the German microbiologist Gerhard Pulverer for contributions to the study of staphylococcal infections in clinical microbiology) is based on a total of five strains isolated from different sources. The cells are nonsporulating, nonmotile, gram-positive cocci. Agar colonies are circular, entire, smooth, nonpigmented or white with yellowish tint, and 4.0 to $8.0 \mathrm{~mm}$ in diameter. All strains are facultative anaerobes which grow best under aerobic conditions. Anaerobic growth on Wilkins agar is evident after 24 to $48 \mathrm{~h}$. The strains cannot be cultivated in semisolid thioglycolate medium. $\mathrm{NaCl}$ does not affect the growth up to concentrations of $15 \%$; the strains are killed in the presence of $17.5 \% \mathrm{NaCl}$. Colonies develop at 25 and $37^{\circ} \mathrm{C}$ after 48 and $24 \mathrm{~h}$, respectively. Weak growth is observed at $10^{\circ} \mathrm{C}$, while at $45^{\circ} \mathrm{C}$ there is no growth.

The five strains produce neither extracellular nor cellassociated coagulase (clumping factor). All of them are resistant to novobiocin. The characteristics are listed in Table 2.

The DNA base composition ranges from 27.0 to $30.0 \mathrm{~mol} \%$ $\mathrm{G}+\mathrm{C}$. The peptidoglycan structure is of the L-Lys-Ala-Gly ${ }_{4-5}$ type. The cell wall teichoic acids contain glycerol, ribose, and $N$-acetylglucosamine. The dominant cellular fatty acids are iso and anteiso branched with 15,17 , and 19 carbon atoms.

Description of the type strain. The type strain, NT215 (=PCM 2443 ${ }^{\mathrm{T}}$; Polish Collection of Microorganisms, Wrocław, Poland), was isolated from a hip infection. The characteristics of the type strain are the same as those given above for the species and in Table 2 . The $\mathrm{G}+\mathrm{C}$ content is $27 \mathrm{~mol} \%$.

The selected characteristics are sufficient to differentiate $S$. pulvereri from other novobiocin-resistant, coagulase-negative Staphylococcus species (Table 5). S. pulvereri can be distinguished from other species by its production of acids from maltose and sucrose (but not from raffinose and D-turanose), by its lack of esculin activity, its peptidoglycan type, and its comparatively low $\mathrm{G}+\mathrm{C}$ content. 


\section{ACKNOWLEDGMENTS}

We are grateful to $\mathrm{H}$. Schrempf for careful reading of the manuscript, M. Lemme for support during its writing, J. Majka and G. Manfio for drawings, and H. Guzik for DNA isolation. We thank H. Przondo-Mordarska for help during phenotypic analysis of $S$. pulvereri strains and J. Chen for help with the computer programs.

\section{REFERENCES}

1. Chesneau, O., A. Morvan, F. Grimont, H. Labischinski, and N. El Solh. 1993. Staphylococcus pasteuri sp. nov., isolated from human, animal, and food specimens. Int. J. Syst. Bacteriol. 43:237-244.

2. Evans, J. B., and W. E. Kloos. 1972. Use of shake cultures in a semisolid thioglycolate medium for differentiating staphylococci from micrococci. Appl. Microbiol. 23:326-331.

3. Felsenstein, J. 1988. Phylogenies from molecular sequences: inference and reliability. Annu. Rev. Genet. 22:521-565.

4. Hájek, V., W. Ludwig, K. H. Schleifer, N. Springer, W. Zitzelsberger, R. M. Kroppenstedt, and M. Kocur. 1992. Staphylococcus muscae, a new species isolated from flies. Int. J. Syst. Bacteriol. 42:97-101.

5. Igimi, S., S. Kawamura, E. Takahashi, and T. Mitsuoka. 1989. Staphylococcus felis, a new species from clinical specimens from cats. Int. J. Syst. Bacteriol. 39:373-377.

6. Kloos, W. E., K.-H. Schleifer, and F. Götz. 1992. The genus Staphylococcus, p. 1369-1420. In M. P. Starr, H. Stolp, H. G. Trüper, A. Balows, and H. G. Schlegel (ed.), The prokaryotes: a handbook on habitats, isolation, and identification of bacteria. Springer-Verlag, New York.

7. Kloos, W. E., T. G. Tornabene, and K. H. Schleifer. 1974. Isolation and characterization of micrococci from human skin, including two new species: Micrococcus lylae and Micrococcus kristinae. Int. J. Syst. Bacteriol. 24:79-101.

8. Lane, D. L. 1991. 16S/23S rRNA sequencing, p. 115-175. In E. Stackebrandt and $\mathrm{M}$. Goodfellow (ed.), Nucleic acid techniques in bacterial systematics. John Wiley \& Sons, New York.

9. Marmur, J., and P. Doty. 1962. Determination of the base composition of deoxyribonucleic acid from its thermal denaturation temperature. J. Mol. Biol. 5:109-118.

10. Minnikin, D. E., and M. Goodfellow. 1980. Lipid composition in the classification and identification of acid fast bacteria, p. 189-256. In M. Goodfellow and R. G. Board (ed.), Microbial classification and identification. Academic Press, London.

11. Mordarski, M., K. Szyba, G. Pulverer, and M. Goodfellow. 1976. Deoxyri- bonucleic acid reassociation in the classification of the 'rhodochrous' complex and allied taxa. J. Gen. Microbiol. 94:235-245.

12. Rigby, P. W. J., M. Dieckmann, C. Rhodes, and P. Berg. 1977. Labelling deoxyribonucleic acid to high specific activity in vitro by nick translation with DNA polymerase I. J. Mol. Biol. 113:237-251.

13. Saiki, R: K. 1990. Amplification of genomic DNA, p. 13-21. In M. A. Innis, D. H. Gelfand, and J. Sninsky (ed.), PCR protocols. Hoffmann-La Roche, Inc., Emeryville, Calif.

14. Saitou, N., and M. Nei. 1987. The neighbour-joining method: a new method for reconstructing phylogenetic trees. Mol. Biol. Evol. 4:406-425.

15. Sanger, F., S. Nicklen, and A. R. Coulson. 1977. DNA sequencing with chain-terminating inhibitors. Proc. Natl. Acad. Sci. USA 74:5463-5467.

16. Schleifer, K. H. 1985. Analysis of the chemical composition and primary structure of murein. Methods Microbiol. 18:123-156.

17. Schleifer, K. H., R. Kilpper-Bälz, U. Fischer, A. Faller, and J. Endl. 1982. Identification of "Micrococcus candidus" ATCC 14852 as a strain of Staphylococcus epidermidis and of "Micrococcus caseolyticus" ATCC 13548 and Micrococcus varians ATCC 29750 as members of a new species, Staphylococcus caseolyticus. Int. J. Syst. Bacteriol. 32:15-20.

18. Schleifer, K. H., and R. M. Kroppenstedt. 1990. Chemical and molecular classification of staphylococci. J. Appl. Bacteriol. Symp. (Suppl.) 69:9S-24S.

19. Sperber, W. H., and S. R. Tatini. 1975. Interpretation of the coagulase test for identification of Staphylococcus aureus. Appl. Microbiol. 29:502-505.

20. Tanasupawat, S., Y. Hashimoto, T. Ezaki, M. Kozaki, and K. Komagata. 1992. Staphylococcus piscifermentans sp. nov., from fermented fish in Thailand. Int. J. Syst. Bacteriol. 42:577-581.

21. Varaldo, P. E., R. Kilpper-Bälz, F. Biavasco, G. Satta, and K. H. Schleifer. 1988. Staphylococcus delphini sp. nov., a coagulase-positive species isolated from dolphins. Int. J. Syst. Bacteriol. 38:436-439.

22. Wilburn, W. J., and D. J. Lipman. 1983. Rapid similarity searches of nucleic acid and protein data banks. Proc. Natl. Acad. Sci. USA 80:726-730.

23. Wilkins, T. D., and S. Chalgren. 1976. Medium for use in antibiotic susceptibility testing of anaerobic bacteria. Antimicrob. Agents Chemother. 10:926-928.

24. Zakrzewska-Czerwińska, J., A. Gaszewska-Mastalarz, G. Pulverer, and M. Mordarski. 1992. Identification of Staphylococcus epidermidis using a 16S rRNA-directed oligonucleotide probe. FEMS Microbiol. Lett. 100:51-58.

25. Zakrzewska-Czerwińska, J., M. Mordarski, M. Goodfellow, and G. Pulverer. 1988. Deoxyribonucleic acid relatedness amongst Staphylococcus epidermidis and Staphylococcus saprophyticus strains. Zentralbl. Bakteriol. Hyg. A 269: 179-187. 